\title{
Relative abundance of Australian White Ibis Threskiornis molluca across the Greater Brisbane region
}

\author{
Stephanie Meyer-Gleaves' and Darryl N. Jones ${ }^{1,2}$
}

'Suburban Wildlife Research Group, Australian School of Environmental Studies, Griffith University, Nathan, QId. 4I I I, Australia.

${ }^{2}$ Corresponding author: Darryl Jones, D.Jones@Griffith.edu.au

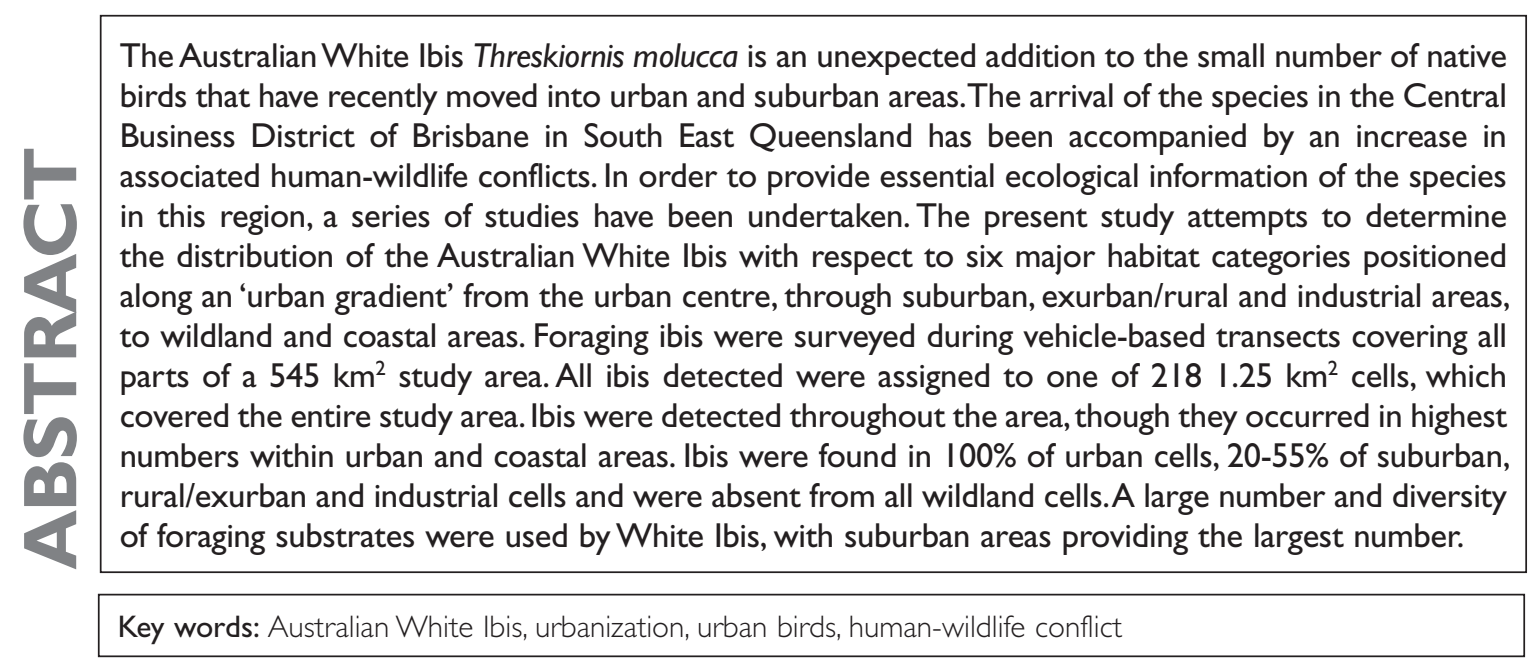

\section{Introduction}

The process of urbanization is increasingly recognized as being one of the most profound influences on global biodiversity (Bessinger and Osbourne 1982; Blair 2001; Chace and Walsh 2006). While it is clear that, for the majority of bird species, urban development is catastrophic (Marzluff 2001; Jones 2003), for a small number the vast alteration of existing environments to one with the characteristics of suburbia has been largely positive (Low 2002). Typically, the species that respond best to these changes are those introduced from elsewhere, often to the detriment of native species (Sewell and Catterall 1998; Low 1999). Nonetheless, some native species have also been able to exploit urban environments and some have undergone dramatic population growth over relatively short time periods. Such species include the Rainbow Lorikeet Trichoglossus haematodus, Crested Pigeon Ocyphaps lophotes and Noisy Miner Manorina melanocephala, which are now extremely common in many Australian cities (Catterall et al. 1991; Fitzsimons et al. 2003; White et al. 2005). In general, the species proliferating tend to be moderately sized $(100-300 \mathrm{~g})$ generalists that are able to take advantage of the abundance of open habitats and super-abundance of garden plantings (Catterall et al. 1991; Jones 2003; White et al. 2005).

The Australian White Ibis Threskiornis molucca (hereafter White Ibis)(Figure 1) is an unexpected addition to this list of native species proliferating in urban areas, the only wading bird to have done so anywhere in the world (Green and Jones 2004). Having been largely absent from urban environments until the 1960s, the species is now thriving

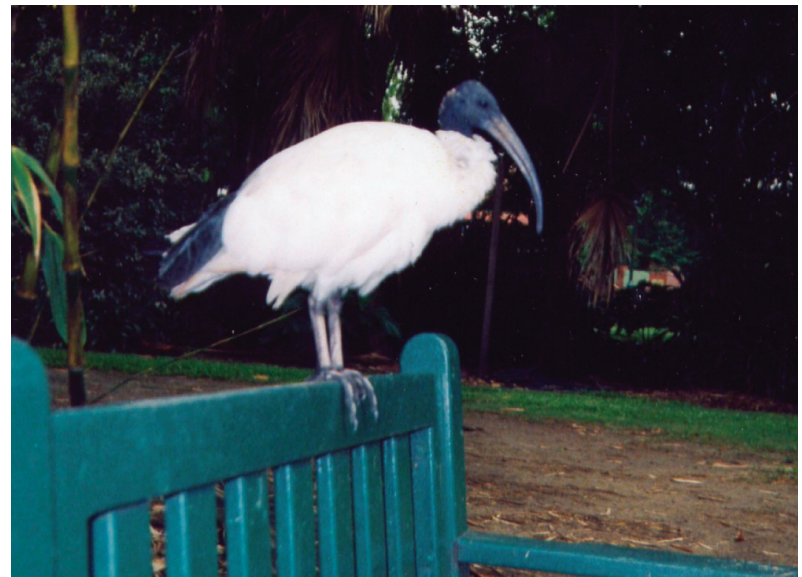

Figure I. The Australian White Ibis is a common sight in many inner city parks in Brisbane (Photograph by $\mathrm{S}$. Meyer-Gleaves).

in a number of Australia's cities (Low 2002). White Ibis have traditionally been associated with the swamps, mudflats and grasslands of South East Queensland (Marchant and Higgins 1990) but were occasionally seen in developed areas, often in the company of the more abundant Straw-necked Ibis Threskiornis spinicollis (Filmer 1938, Vernon 1968). A series of annual bird counts of the Brisbane region by the Queensland Ornithological Society (QOS) undertaken 1972 -1983 confirmed this relative rarity with an average of only 3.7 White Ibis reported each year (Woodall 1985).

During the early 1990s, however, the species expanded into suburban and inner city Brisbane, eventually 
establishing a breeding colony in the City Botanic gardens in the Central Business District (Lowe 1999). Since that time, the number of ibis present in Brisbane's inner city parklands, and squares in particular, has increased significantly, leading to a number of management issues for parkland staff and the local council, including the fouling of parklands, mild harassment of picnickers and concerns over hygiene in open-air cafes (Jones et al. 2000; Low 2002; Green and Jones 2004).

The Greater Brisbane region now supports at least four large breeding colonies as well as several landfills that are frequented by large numbers of foraging ibis on a daily basis (Green and Jones 2004). It has been widely assumed that the presence of these landfills is at least partially responsible for the increased abundance of White Ibis in the region (Lowe 1999; Shaw 2000, Shaw and Murray 2005, Murray and Shaw 2006).

The development of sound and effective approaches to the management of wildlife-human conflicts must be based on suitably detailed ecological and behavioural information (Jones et al. 1998, 2003). Although some progress in this regard has commenced in Sydney (Ross 2004) and on the Gold Coast (Shaw and Murray 2005), our understanding of many essential aspects of the White Ibis in an urban setting remains fragmentary (Green and Jones 2004, Murray and Shaw 2006). The present study is part of a series designed to increase understanding of the synanthropy ${ }^{1}$ of this species in Brisbane.

This paper provides information on the presence of White Ibis in six predominant habitat types occurring in the Greater Brisbane Region. Our approach employed an 'urban gradient' landscape perspective (Marzluff et al. 2001) to systematically assess the presence or absence of the species in urban, suburban, rural/exurban, forested, industrial and coastal environments of the region. We assessed the null hypothesis that White Ibis were evenly distributed in each of the main environment categories present.

The aims of the present study were to: (1) determine the presence/absence of White Ibis along the urban gradient of the Greater Brisbane Region; (2) determine whether White Ibis were evenly distributed within and between environment types; and (3) ascertain the preferred habitat types used by the species.

\section{Methods}

\section{Study area}

Surveys were conducted around Brisbane, Australia $\left(27^{\circ} 33^{\prime} \mathrm{S}, 153^{\circ} 03^{\prime} \mathrm{E}\right)$, which is situated on the subtropical south-eastern coast of Queensland. It receives approximately 1200-1600 mm of rainfall annually (Yencken and Wilkinson 2000) and has an average temperature range (data from 1961-1990) of $15-24^{\circ} \mathrm{C}$ (Australian Bureau of Meteorology 2002). Brisbane city has developed around the Brisbane River and, as one of the fastest growing regions of Australia, is expected to be the second largest city in the country by

\section{0 (Australian Bureau of Statistics 2001).}

The Greater Brisbane Region covers an area of approximately $3000 \mathrm{~km}^{2}$ with Brisbane city itself accounting for $1220 \mathrm{~km}^{2}$ of the land area (Ryan 1995). Prior to European settlement the region was covered by a wide range of habitats including sub-tropical rainforest, dry eucalypt forest, woodlands, coastal (wallum) heath, wetland areas, mangroves and intertidal zones (Ryan 1995). Within the last 150 years, approximately two-thirds of the natural vegetation cover has been transformed, firstly to agricultural and pastoral land, and more recently, to residential areas (Sewell and Catterall 1998).

\section{Habitat categories}

A triangular 'wedge' of the Greater Brisbane Region (approximately $19 \mathrm{~km}$ x $23 \mathrm{~km} \times 26 \mathrm{~km}$ ) was selected to examine the habitat use and presence and absence of the White Ibis at the regional scale (see Figure 2). This area, which is representative of the habitats present in the Brisbane region as a whole, covered a total of $545 \mathrm{~km}^{2}$ representing approximately $18 \%$ of the total land area of the entire Greater Brisbane region. The southern border of the study site extended east from the city center to the outer coastal suburb of Victoria Point. The coastline formed the eastern border and extended from Victoria Point headland to the northern tip of Fisherman Island at the mouth of the Brisbane River. The southern bank of the Brisbane River formed the northern border of the study site from its mouth in Moreton Bay to the city center, Kangaroo Point reach.

This survey area was selected as being representative of all habitat types found along the urban gradient of this area from the CBD through suburbs and rural environments to the coast. The study area was divided into six habitat categories: urban, suburban, rural/exurban, wildland, industrial and coastal (see Marzluff et al. 2001). The entire study area was divided into cells each covering 1.25 $\mathrm{km}^{2}$ (based on each map of the 2001 UBD Brisbane Street Directory being divided evenly into 16 cells). Each cell was subsequently assigned to a habitat category based on the primary land use as the cell was surveyed. A cell was designated as coastal if the cell contained any coastline even if this was not the dominant land use. The first four categories were those environment (habitat) categories suggested by Marzluff et al. (2001), while the latter two were new categories included for the purposes of the present study. These six habitat categories are defined as follows:

Urban: High building density with most of the land being covered by buildings primarily used for commerce, service or industry. Multi-family housing and multistoried buildings with little or no garden or lawn space are characteristic.

Suburban: Moderate to high building density, primarily with single-family housing with lot sizes 0.1-1.0 ha. Basic services, light industry, and multi-family housing are interspersed with the typical single-family dwellings. Most

\footnotetext{
I Synanthropy = association with humans or their dwellings.
} 


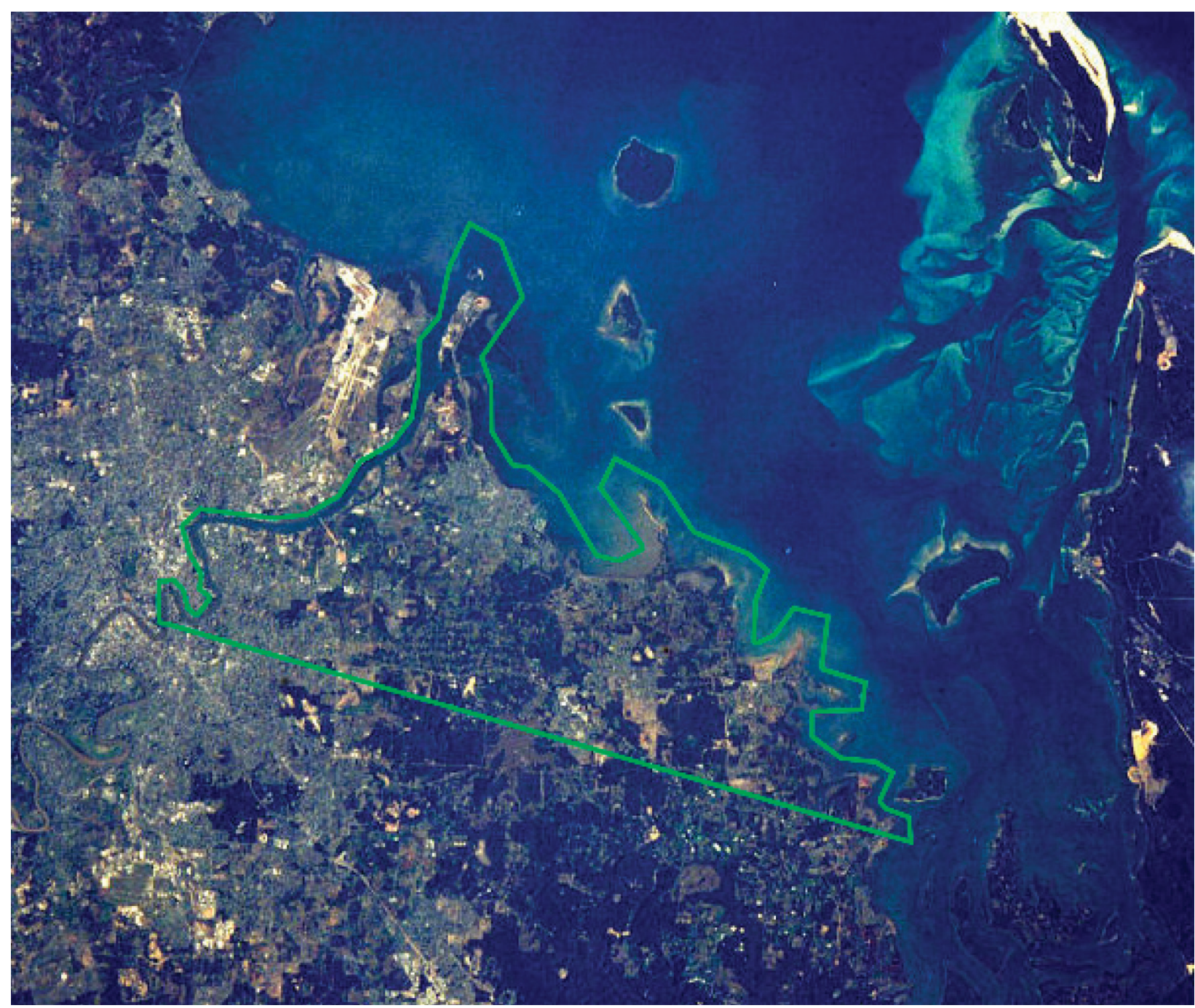

Figure 2. Satellite image of a section of the Greater Brisbane Region showing the outline of the selected study area. The outlined study area comprises an area of land of approximately $545 \mathrm{~km}^{2}$. (Source: PC World Magazine 2003,edited by Alex Meyer-Gleaves).

buildings single or double storied and lawns and gardens were common.

Rural/Exurban: Farms and large properties dominated these sparsely settled areas. The pattern of settlement varied widely and miscellaneous patterns of vegetation reflect variable land use. The canopy cover was generally sparse often with grassy under-vegetation.

Wildland: Areas dominated by natural vegetation. Within Brisbane these were primarily remnants of the original forest vegetation. There are no dwellings and human disturbance was minimal.

Industrial: Areas characterized by large industrial buildings and warehouses, generally interspersed with car parks, roads, relatively small areas of landscaped gardens and neglected areas of non-vegetated land.

Coastal: Areas of land situated within $1 \mathrm{~km}$ of the coastline, characterized by parks, nature strips, coast roads, mudflats, beaches, single-family housing and occasionally multistorey family housing.
Note that no surveys were conducted within $1 \mathrm{~km}$ of either landfills or breeding colonies as we wanted to avoid the immediate influence of these important foraging sites. The role of landfill in the growth of urban ibis populations is well-known though poorly understood (Murray and Shaw 2006).

\section{Surveys}

Foraging ibis were detected during vehicle-based observational surveys conducted systematically along roads throughout the entire study area with the route chosen to ensure that every cell was covered wherever possible. Where roads limited access to large tracts of land, sites were covered on foot. At no time was private property entered with observations being undertaken from the periphery whenever possible. Various government and private facilities in the study area, such as schools, wastewater treatment plants and industrial grounds, were surveyed on foot with the appropriate permission. 
Surveys were conducted between December 2002 and February 2003, during a period of relatively diminished rainfall. Surveys were undertaken throughout the day but traveling routes designed to ensure that sites within local areas were surveyed at varying times. Whenever White Ibis were detected, the habitat category, site location, group size, foraging substrate, date and time were recorded.

\section{Analyses}

The mean numbers of ibis detected in habitats types were compared using a one-way Analysis of Variance. To assess habitat preferences, each cell was classified as one of the six habitat types (see above) based on the dominant habitat present. Contingency tables were then used to compare the proportion of cells of each habitat type supporting ibis with the expected frequencies of all cells; only cells with ibis were used in these tests. Similarly, contingency tests were used to assess the use of substrate types. In both cases, the null hypothesis was that habitat type or substrate type were used equally was tested, with the groups adjusted according to reflect the number of cells of each type.

\section{Results}

White Ibis were found commonly throughout the region in all but fully forested sites. Because the surveys included every cell within the entire study area, the results are also indicative of habitat selection by foraging White Ibis.

\section{Abundance and group sizes along the urban gradient}

White Ibis were detected in each of the seven urban cells, and in $20-55 \%$ of suburban, rural/exurban and industrial cells but were absent from all wildland cells
(Table 1). Despite the presence of White Ibis in all urban cells, a contingency table comparison of the number of cells occupied with the number expected (based on proportional distribution of all occupied cells) was not significant $\left(\mathrm{X}^{2}=6.2\right.$, d.f. $=5$, N.S. $)$. This was, however, most likely due to the relatively small number of cells that made up the entire urban component of the study site.

The mean number of White Ibis detected per cell in the urban environment was almost twice that of the next highest habitat (coastal) and much higher than that of all other habitats (Table 2). This measure of abundance was significantly higher for the urban environment than for all other environments $(\mathrm{F}=28.42$, d.f. $=5,217, \mathrm{p}<0.001)$. However, this result is largely an artifact of the relatively smaller number of cells available for the urban habitat. This is illustrated by group size data (Table 2) which shows that mean group size was typically 7-10 for all habitats in which ibis were detected; mean group sizes were not significantly different between habitats.

Nonetheless, White Ibis were most frequently observed as single birds or small parties; the modal group size of 1-5 White Ibis was recorded for more than half of all observations.

\section{Foraging substrate use along the urban gradient}

Each of the habitat types surveyed offered different foraging opportunities for White Ibis. During observations the substrate being used by foraging White Ibis was recorded within each habitat type. In an attempt to assess foraging site use, the number of foraging birds in each identifiable foraging substrate was recorded. The proportion of observations for each substrate was then compared within habitat types.

Table I. Number and percentage of cells within the study area for each habitat category, and the number and percentage of cells occupied by Australian White Ibis in Greater Brisbane

\begin{tabular}{lcccc}
\hline Habitat category & Number of cells & \% of Total & $\begin{array}{c}\text { Number of cells } \\
\text { occupied }\end{array}$ & \% of cells occupied \\
\hline Urban & 7 & 3.2 & 7 & 100.0 \\
\hline Suburban & 101 & 46.3 & 45 & 44.5 \\
\hline Rural/exurban & 46 & 21.1 & 19 & 41.3 \\
\hline Industrial & 20 & 9.2 & 40 & 20.0 \\
\hline Wildland & 4 & 1.9 & 0 & 0 \\
\hline Coastal & 40 & 18.3 & 22 & 55.0 \\
\hline Total & 218 & 100.0 & 97 & 44.5 \\
\hline
\end{tabular}

Table 2. Mean number of Australian White lbis per cell, mean group size, group size range and most frequent group size category for each habitat category. indicates that insufficient sightings were recorded to provide a group size range.

\begin{tabular}{lcccc}
\hline Habitat category & Mean. number of ibis per cell & Mean group size & Group sizerange & Modal group size range \\
\hline Urban & 13.57 & $10.55 \pm 8.09$ & $1-32$ & $1-5$ \\
\hline Suburban & 4.58 & $7.18 \pm 12.52$ & $1-49$ & $1-5$ \\
\hline Rural/Exurban & 2.7 & $15.11 \pm 33.90$ & $1-40$ & $1-5$ \\
\hline Industrial & 2.6 & $13.0 \pm 9.49$ & $1-24$ & $\sim$ \\
\hline Wild land & 0 & 0 & $\sim$ & $\sim-5$ \\
\hline Coastal & 6.93 & $19.88 \pm 9.97$ & $1-42$ & $1-5$ \\
\hline
\end{tabular}


For urban, suburban and rural/exurban habitats, White Ibis foraged significantly more in certain substrate types. Urban habitat contained two foraging substrates, with urban parks (8 of 9 observations) being used significantly more than shopping mall areas $\left(X^{2}=5.44\right.$, d.f. $=1, p$ $<0.025)$. As expected, suburban habitats provided a far greater range of foraging substrates with a total of 11 being identified here (Fig. 3). Of these, the five most frequently used substrates (suburban parks, suburban streets, sporting fields, vacant land and pasture, respectively), accounted for $84.4 \%$ of the 77 observations; all were characterized as being predominately lawn or pasture $\left(\mathrm{X}^{2}=60.04\right.$, d.f. $=10, \mathrm{p}<0.005)$. In rural/exurban sites, however, ibis were more commonly observed foraging in the immediate vicinity of freshwater bodies (primarily farm dams; 9 of 16 observations) than any of the other substrates $\left(\mathrm{X}^{2}=\right.$ 13.37, d.f. $=4, \mathrm{p}<0.005)$.

Only four groups of foraging White Ibis were detected in the industrial habitat, each group being seen on a different foraging substrate (waterbody, sewage treatment plant, parkland and pasture). White Ibis detected in coastal habitats were found equally in only two different substrates, coastal park and mudflats.

Parklands were commonly used by foraging ibis in four of the five habitats (urban (88.9\% of observations), coastal (50.0\% of observations), industrial $(25.0 \%$ of observations), and suburban (23.0\% of observations)); the rural/exurban habitats did not contain this substrate type.

\section{Discussion}

White Ibis were present commonly though unevenly throughout the urban gradient of Greater Brisbane, but were absent from forested wildland. The proportion of cells occupied was greatest in the city centre and decreased from suburban to rural/exurban and industrial habitats. In coastal areas, ostensibly the most 'natural' habitat present in the region, over half of all cells sampled were occupied by ibis.

The abundance of White Ibis detected in this study contrasts markedly with earlier surveys from the Brisbane region. In 1973, a total of only 25 White Ibis was recorded during the QOS annual bird count conducted throughout the entire region (Perkins 1974). Summarising data from this event for the period 1972-1983, Woodall (1985) obtained a yearly average of less than 20 individuals. Unfortunately, no regional data since 1983 are available. The limited use of suburban gardens by White Ibis is also supported by Woodall $(1995,2002)$, who did not report the presence of White Ibis in such habitats of Brisbane during either the 1979-1980 or 1999-2000 Queensland garden bird surveys. Although no data exist on the population size for the region, the present survey allows us to conclude that the abundance of the species has increased dramatically during the last two decades. Moreover, the present study supports suggestions (e.g., IMCG 1996, Lowe 1999, Low 2002) that the White Ibis has become a synanthropic species only recently. Low (2002), for example, speculated that Brisbane's inner citydwelling ibis were unknown until the late 1990s.

Australian White Ibis typically breed in response to the seasonal flooding of wetlands, and are known to move away in large numbers when formerly suitable breeding areas become dry (Marchant and Higgins 1990). Historically, South East Queensland appears to have been used by the species as a dry season refuge when conditions inland were unfavourable (Carrick 1962; McKilligan 1979; Gosper et al. 1983). Similarly, during drought conditions in southern

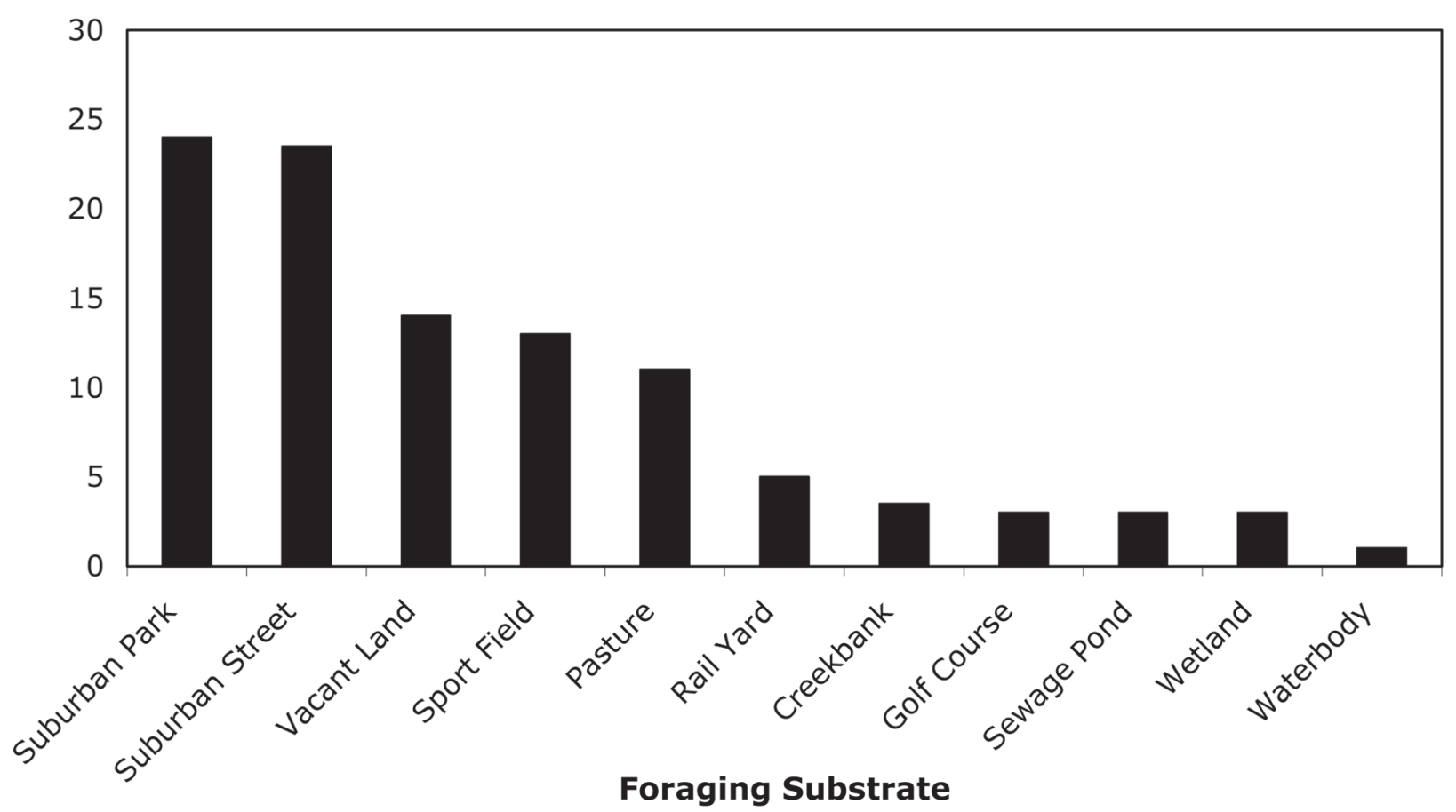

Figure 3. Foraging substrates utilised by Australia White lbis in the suburban habitat category of the study site showing the proportion of observations in each substrate. 
New South Wales, Carrick (1962:79) reported that White Ibis had moved coastward and were "forced to seek food in unusual places". In apparently the first record of White Ibis utilizing an urban environment, in 1957, Carrick (1962) noted the species within the suburbs of Canberra, feeding in gardens and on the grass verges of streets. This was apparently a temporary influx; during the early 1980s, the Canberra Garden Bird Survey reported the species at very low numbers (Veerman 2003). By 2002, however, the species was being reported by $20 \%$ of observers, with flocks of 100 being frequently observed (Veerman 2003).

It is noteworthy that historical records regard the Straw-necked Ibis rather than White Ibis as the more abundant species seen in the Brisbane region (Vernon 1968). Reporting on species seen in an inner Brisbane park, Filmer (1938: 36) reports Straw-necked Ibis as "not plentiful" but does not mention White Ibis, while Jack (1938:120) recorded both species as being occasional visitors "particularly when there are plenty of grasshoppers". Although not analyzed here, Strawnecked Ibis were detected infrequently and in generally low numbers in the present study: of a total of 68 individuals recorded, $84 \%$ were seen in the suburban and the remainder in rural/exurban environments. Interestingly, the two habitats where White Ibis were detected in the highest densities, urban and coastal, were not utilised at all by the Straw-necked Ibis during this study. In comparison, a contemporaneous study conducted in rural areas west of Brisbane (Jones and Nealson 2003) found Straw-necked Ibis to be up to four times more common than White Ibis. The Glossy Ibis Plegadis falcinellusi was only detected twice; on both occasions single individuals were observed foraging in suburban wetlands. These findings support the contention that White Ibis are unique among their cogeners within the region in the extent of their utilisation of the urban environment.

\section{Use of different habitats along the urban gradient}

Urban habitat. Each cell within the urban area contained parklands or pedestrian malls providing opportunistic foraging opportunities in the form of well-watered lawns and garden beds as well as some discarded human food; most also contained permanent sources of water. During the day, trees, shelter roofs and park benches were used for diurnal roosting, and suitable night roosting trees occurred in all three of the larger parklands (Jones et al. 2000).

The urban mall was the most artificial environment utilised by White Ibis within the study area. White Ibis visited this site infrequently although no more than four birds were observed there at any one time. In addition to foraging in the garden beds present in the mall, White Ibis foraged in bins and on the ground for discarded food waste, as well as soliciting from people eating in the mall.

Although White Ibis have been previously known to enter suburban areas occasionally to forage in gardens, playing fields and road verges (Marchant and Higgins 1990), their use of the Central Business Districts was unknown until recently (Lowe 1999). They were first recorded as urban birds in Sydney in the late 1970s and subsequently in Melbourne, Perth and the Gold Coast (Lowe 1999, Ross 2004). In 2000, approximately 80-120 birds occupied a breeding colony in the City Botanic Gardens, only $0.5 \mathrm{~km}$ from the CBD (Jones et al. 2000). These birds foraged primarily in the parkland surrounding the colony although later in the day groups of up to 20 frequently flew to inner city parks to scavenge (Jones et al. 2000). The presence of these birds generated a significant nuisance for local authorities, eventually leading to active dispersal of the colony and other management action (D. Jones, unpublished data). Nonetheless, White Ibis have now established a permanent urban presence in Brisbane, although breeding activities are extremely limited within urban areas (Meyer-Gleaves 2003). Foraging ibis prefer the comparatively quieter habitats of urban parks, where almost all of their daily dietary intake is obtained, with occasional visits to pedestrian malls for opportunistic scavenging (Meyer-Gleaves 2003).

Suburban habitat. White Ibis were patchily distributed throughout the suburban environment of the study area. The species appeared to avoid areas that were relatively dry and lacked a source of open water, but were often more common in sites closer to coastal environments or the Brisbane River. These areas tended to be older areas, with established gardens and parks possibly providing superior foraging opportunities.

Suburban foraging substrates - parks, road verges, vacant areas of grass and sporting fields - typically contained elements of their 'natural' environment especially friable soil enabling probing, extensive lawns or pastures, and permanent bodies of freshwater (Meyer-Gleaves 2003). Nonetheless, White Ibis also visited parks devoid of these features when they provided opportunities to scavenge human-derived foods. However, such visits tended to be transitory (Meyer-Gleaves 2003).

Suburban gardens were not, however, a preferred foraging substrate, possibly because the structure of most houselots prevents the progressive movements of small groups of foraging individuals that is typical of foraging ibis (Marchant and Higgins 1990). Both Catterall et al. (1991) and Woodall $(1995,2002)$ found very few White Ibis in Brisbane's suburban gardens although the species does appear to use this substrate more frequently in Canberra (Veerman 2003).

Rural/exurban and industrial habitats. The rural/exurban environment of the study area provided White Ibis with five different habitats, all of which share similarities with their 'natural' habitat. The most favoured of these was freshwater bodies (dams and ponds), especially those surrounded by tall trees suitable for roosting and shade. Industrial sites offered limited foraging opportunities. All four sightings of White Ibis groups in this habitat occurred in riverine environments.

Coastal habitat. The extensive coastal mudflats of Moreton Bay represent the traditional foraging habitat of the species in this region and this zone supported the second highest abundance of White Ibis. 


\section{Conclusions}

White Ibis were found to inhabit wetlands of almost any sort, including estuaries, mangrove swamps, artificial lakes and beaches but also occurred on pastures and drier ground, including parks, road verges, disturbed areas around farms and suburban paddocks. This is consistent with the use of a wide range of natural and artificial habitats by White Ibis as reported by Marchant and Higgins (1990). Historically, however, the species' natural foraging preference has been for marine and aquatic habitats that provide a foraging substrate of shallow water over soft substrates (Marchant and Higgins 1990). Traditionally, grasslands and agricultural land were used primarily only when invertebrate prey was abundant (Carrick 1962). The present examination of the use of foraging habitats suggests that a significant move away from aquatic and marine habitats has occurred in order for the species to be able to successfully utilise the city environment. A large variety of 'new' yet suitable terrestrial habitats are available in the city environment and the species appears to have been able to utilise these resources extensively (Meyer-Gleaves
2003). White Ibis preferred parks, areas of lawn and pasture, freshwater bodies, wetlands, creek banks, and mudflats irrespective of the position along the urban gradient in which these occurred.

The White Ibis is one of a small number of native bird species to have very effectively moved into the artificial habitats provided by the process of urbanization. In the case of the White Ibis, this transition appears to have been extraordinarily rapid (Low 2002, Murray and Shaw 2006). Although the reasons that promote synanthropy remain largely unknown in any species to have successfully invaded urban environments, our investigations suggest that White Ibis are employing existing modes of opportunistic foraging although in novel substrates (Meyer-Gleaves 2003). However, as in many synanthropic species, a critical behavioural prerequisite for urban life appears to be an ability to remain undisturbed by human presence and activities (Partecke et al. 2006). By reducing the natural (and adaptive) tendency to flee at the approach of humans, individuals that can control this urge may benefit for access to new foraging opportunities (Rollinson and Jones 2006), an approach clearly adopted by White Ibis.

\section{References}

Australian Bureau of Meteorology. 2002. Queensland Climate. Commonwealth of Australia. http://www.bom.gov.au. (Accessed 21-10-2002).

Australian Bureau of Statistics. 2001. Australia now: population distribution. http://www.abs.gov.au. (Accessed 21. 10-2002).

Bessinger, S.R. and Osborne, D.R. 1982. Effects of urbanization on avian community organization. Condor 84: 75-83.

Blair, R.B. 2001. Creating a homogeneous avifauna. Pp. 461488 in Avian Ecology and Conservation of Birds in an Urbanizing World, edited by J.M Marzluff, R. Bowman, and R. Donnelly. Kluwer Academic, Norwell, MA.

Carrick, R. 1962. Breeding, movements, and conservation of ibises (Treskiornithidae) in Australia. CSIRO Wildlife Research 7: 71-88.

Catterall, C.P., Green, R.J. and Jones, D.N. 1991. Habitat use by birds across a forest-suburb interface in Brisbane: implications for corridors. Pp. 55-62 in Nature Conservation 2: The Role of Corridors, edited by D.A. Saunders and R.J. Hobbs. Surrey Beatty and Sons, Chipping Norton.

Chace, J.F., and Walsh, J.J. 2006. Urban effects on native avifauna: a review. Landscape and Urban Planning 74: 46-69.

Gosper, D.G., Briggs, S.V. and Carpenter, S.M. 1983. Waterbird Dynamics in the Richmond Valley, New South Wales, 1974-77. Australian Wildlife Resources 10: 319-327.

Green, B. and Jones, D.N. 2004. Living with wildlife: Australian White Ibis. Report to Brisbane City Council, Suburban Wildlife Research Group, Griffith University, Brisbane.

Filmer, I.G. 1938. The birds of Victoria Park, Brisbane. Queensland Naturalist 18(1), 34-39.

Fitzsimons, J.A., Palmer, G.C., Antos, M.J., and White, J.G. 2003. Refugees and residents: densities and habitat preferences of lorikeets in urban Melbourne. Australian Field Ornithology 20, 2-7.

IMCG Report. 1996. Working Towards A Natural Balance: A report into the findings of the Ibis Management Coordination Group's pilot program. Ibis Management Coordination Group. Gold Coast, Australia.

Jack, N. 1938. Ornithology of the Mt. Coot-tha Reserve, Taylor Range. Queensland Naturalist 10(6), 114-124.

Jones, D.N. 2003. Contemporary urban ecology: the view from the Antipodes. Pp. 745-753 in Ecosystems and Sustainable Development IV, Vol. 2. edited by E. Tiexxi, C.A. Brebbia and J.L. Usó. WIT Press, Southampton.

Jones, D.N., Enck, J.W., Siemer, W.F, Decker, D.J. and Brown, T.L. 1998. An introduction to human dimensions in wildlife management: Taking the North American experience to Australia. Human Dimensions Research Unit, Cornell University.

Jones, D.N. and Nealson, T. 2003. Ti Tree Waste management Facility Base-Line Study: Abundance and habitat Use of Significant Species. Report to Collex Pty Ltd, Suburban Wildlife Research Group, Griffith University, Brisbane.

Jones, D.N., Rhodes, M., Rollinson D. and Vogel, U. 2000. The presence of ibis, possums and brush-turkeys in the Brisbane City Botanic Gardens. A Report to the BCC. Suburban Wildlife Research Group, Griffith University, Brisbane.

Low, T. 2002. The New Nature. Penguin, Sydney

Lowe, K. 1999. The dirt on Ibis. Nature Australia Autumn, 27-33.

Marchant, S. and Higgins, P.J. 1990. Handbook of Australian, New Zealand and

Antarctic Birds: Volume 1 Ratites to Ducks. Oxford University Press, Melbourne.

Marzluff, J.M. 2001. Worldwide urbanization and its effect on birds Pp. 19-47 in Avian Ecology and Conservation of Birds in an Urbanizing World, edited by J.M Marzluff, R. Bowman, and R. Donnelly. Kluwer Academic, Norwell, MA..

Marzluff, J.M., Bowman, R. and Donnelly, R. 2001. A historical perspective on 
urban bird research: trends, terms, and approaches. Pp. 1-17 in Avian Ecology and Conservation of Birds in an Urbanizing World, edited by J.M Marzluff, R. Bowman, and R. Donnelly. Kluwer Academic, Norwell, MA.

McKilligan, N.G. 1979. The Ecology of the Straw-necked Ibis In Winter at Toowoomba, South-east Queensland. Sunbird 10(3/4): 49-57.

Meyer-Gleaves S. 2003. Synanthropy of the Australian White Ibis Threskiomis molucca, in the greater Brisbane region. Honours Thesis, Griffith University, Brisbane.

Murray, N. J. and Shaw, P. P. 2006. Breeding biology of the Australian White Ibis Threskiorinis molucca at an urban breeding colony, south-east Queensland. Corella 30: 41-45.

Partecke, J., Schwabl, I. And Gwinner, E. 2006. Stress and the city: Urbanization and its effects on the stress physiology in European blackbirds. Ecology 87 1945-1952.

Perkins, D.L. 1974. Annual Bird Count, 1973, Queensland Ornithological Society. Sunbird 5(1): 1-9.

Rollinson, D. J. and Jones, D. N. 2006. Tolerance of Australian magpies Gymnorhina tibicen towards humans: A comparison along an urban gradient. Australian Field Ornithology 23: 29-35.

Ross, G. A. 2004. Ibis in Urban Sydney: a Gift from Ra or a Pharaoh's Curse? Pp. 148-152 in Urban Wildlife: more than meets the eye, edited by D. Lunney and S. Burgin. Royal Zoological Society of New South Wales, Mosman, NSW.

Ryan, M. (Ed). 1995. Wildlife of Greater Brisbane. Queensland Museum, Brisbane.

Sewell, S.R. and Catterall, C.P. 1998. Bushland modification and styles of urban development: their effects on birds in southeast Queensland. Wildlife Research 25: 41-63.
Shaw, P.P. 2000. Australian White Ibis at South Bank, Brisbane Qld. Report to Brisbane City Council. Eco-Sure Environmental Consultants, Tugan, Qld

Shaw, P.P. and Murray, N. J. 2005. Australian White Ibis Management Program: Annual Report 2004/2005. Tweed - Gold Coast Region. Report to the Ibis Management Coordination Group. Eco-Sure Environmental Consultants, Tugan, Qld .

Vernon, D.P. 1968. Birds of Brisbane and Environs. Queensland Museum, Brisbane.

Veerman, P.A. 2003. Canberra Birds: A Report On The First 21 Years of Garden Bird Survey. Philip A. Veerman, Kambah, Canberra.

White, J.G., Antos, M.J., Fitzsimons, J.A., and Palmer, G.C. 2005. Non-uniform bird assemblages in urban environments: the influence of streetscape vegetation. Landscape and Urban Planning 71: 123-135.

Woodall, P. 1985. Waterbird populations in the Brisbane Region, 1972-83, and correlates with rainfall and water heights. Australian Wildlife Resources 12: 495-506.

Woodall, P. 1995. Results of the QOS Garden Bird Survey, 1979-80, With Particular Reference To South-East Queensland. Sunbird 25(1): 1-17.

Woodall, P. 2002. The Birds Queensland Garden Bird Survey, 1999-2000. Sunbird 32(2\&3): 37-51.

Yencken, D. and Wilkinson, D. 2000. Resetting the compass: Australia's journey towards sustainability. CSIRO Publishing, Collingwood. 